\title{
Freedom in music on the example of the works of Karlheinz Stockhausen and Iannis Xenakis
}

\begin{abstract}
In her article titled Niebezpieczne związki, czyli o granicach wolności $w$ sztuce i $w$ życiu [Dangerous liaisons, or on the limits of freedom in art and life] Elżbieta Korolczuk (2013) claims that the sense of personal freedom and independence from other people - not only in the sense of intellectual and aesthetic influences, but also familial and emotional ties - is often perceived as necessary in order to create new, original works, to be a truly creative individual'. It is not difficult to find new and original works in the oeuvre of Karlheinz Stockhausen and Iannis Xenakis and, paraphrasing the words of Maria Anna Potocka (2013) - it is thanks to them that 'the world has modernised itself and freed itself from outdated values'. In relation to creative work in music, this 'sense of personal freedom and independence from other people' leads, on the one hand, to the 'freedom of music' and, on the other, ensures achieving 'freedom in music'. The aim of this discussion is to point to those threads in the statements of Stockhausen and Xenakis, and those features of their works, which testify to the specific manifestations of the 'freedom in music' created by them.
\end{abstract}

KEYWORDS: freedom, music, Karlheinz Stockhausen, Iannis Xenakis

\section{Introduction}

I interpret the phrase 'freedom of music' as referring to such kind of manifestation of a 'sense of personal freedom [of the composer - JHJ] and independence from other people' (Korolczuk, 2013) which leads to setting the artist free of all factors external to music (of a cultural and political nature), and of all social determinants. In this context, the achievement of freedom by music is linked to freeing it of all social expectations or demands, which means it is not regarded functionally. Such music is created and 'lives', in a sense, for itself.

On the other hand, I interpret 'freedom in music' as the intentional endowing of music with such features as make it fully original and new in relation to tradition. In this respect, the decisive factors are those which are internal in relation to music, conditioned by the creative attitude of the composer who, in his creative strategy is guided, to a lesser or greater degree, by freedom of choice. I define internal factors as impulses of various provenance which prompt the composer towards specific actions. These are the critical impulses resulting from the fact 
that, according to Potocka - 'an artist - carried by the wave of energy of a free person - examines the world critically and undermines things which to others appear obvious or revealed' (Potocka, 2013). These impulses also have a philosophical and/or aesthetic context, when the composer breaks out of the ruling paradigm with his or her music. This 'freedom in music' may be determined by one of the kinds of impulse just mentioned, or their configuration. However, the specific creative poetics, creative idea or ideas, the composer's life experience or interests outside music, which are undoubtedly individual and idiomatic to a given artist, influence the uniqueness of the 'freedom in music' being achieved. To this purpose, each composer freely chooses the musical material, compositional techniques, the manner of constructing the work or including within it specific genre features. In the final analysis, 'freedom in music' often implies intentional redefinition of the functions of the composer, performer and the audience. Unlimited 'freedom in music' leads to bestowing on the listener the function of the performer equalised with the function of the composer. Limited 'freedom in music' favours retaining the traditionally understood functions: the composer creates the work, the performer interprets it, and the listener apprehends it. Clearly, between these extreme situations there also appear intermediate states, but their presence depends on the degree of participation and the configuration of the determinants of 'freedom in music' indicated above.

It is thus worth taking a closer look at specific cases of shaping 'freedom in music' taken from self-reflective statements and selected works of Stockhausen and Xenakis. These are composers who are undoubtedly associated with progress, novelty and originality in the music of the second half of the twentieth century, thus composers who cannot be claimed to lack 'a sense of personal freedom and independence'. It is also worth remembering that - as was pointed out by Korolczuk - in practice, freedom is a relative phenomenon, and the process of negotiating or establishing the extent of (in)dependence of individuals or groups always takes place at the crossing place between what is individual and what is social, cultural and political; it is a process and not a state, and the individual is 'always entangled in a net of emotional, economic and symbolic bonds' (Korolczuk, 2013).

\section{Self-reflection of Karlheinz Stockhausen}

Undoubtedly Stockhausen's ,freedom in music' reflects the critical-philosophical impulse arising gradually in the composer's awareness. His authorial commentaries to premiere performances of his own works abound in statements expressing both his attitude to the music of past epochs, and revealing significant aspects of self-reflection in relation to the music he was creating. In Stockhausen's case the ,sense of personal freedom and independence' seems to be inextricably linked to the concepts of freedom (Freiheit), novelty (das Neue) and a particular kind of spirituality (das Geistig-Geistliche ${ }^{1}$ ) postulated by the composer. At the premiere of his Litanei 97 in 1997 Stockhausen said:

\footnotetext{
1 'The notion 'das Geistig-Geistliche' emphasizes the balance between reason and religion in
} 
As with everything that I start, there are three main directions for me [...]. One of them is freedom. Since I decided [...] to live the life of a composer, freedom always appears before me as the highest ideal [...] The work to be premiered tonight [...] is created in total freedom, independent of limitations and principles and - so to say - ideology. [...] The second one is novelty. [...] to compose something that excludes everything I knew [...] What matters is the new, the freedom in usage, so as not to use anything that had been used by others - even not to accept any social dependence. [...] The new is to be mental-spiritual. ${ }^{2}$ (Stockhausen, 1998a, pp. 19-20)

The association between freedom and novelty in the quoted passage is not surprising, since such a paradigm seems to be quite generally adopted in the criticism of twentieth-century art. As a twentieth-century artist, Stockhausen was almost 'obliged' to shape 'freedom in music' using novelty. In the understanding of art critics this particular creative imperative results from the extraordinary characteristics with which an artist is endowed, and from the special social function which the artist fulfils.

The artist looks deeper than the ordinary person. The places on which the artist focuses attention are subjected to 'analytical torment' and pushed off-balance. This means that a somnolent fragment of reality becomes a living inspirator of change. Using art as a critical tool in relation to the collective consciousness protects against ossification in the worldview of the previous generation and contributes to cultural evolution. For centuries creative artists were valued for playing precisely this role; they enforced a change of point of view and that meant that the perception of the world was brought up to date. [...] The twentieth century totally freed the artist from any obligations. From that moment his role consists in manifesting displeasure with social norms, in undermining hierarchies, ridiculing superstitions, shaking up religious self-righteousness and digging around in anxieties and things left unsaid. The manner of expressing this criticism intensity of content with economy of form - is the measure of artistic value. Those artists who, at the right moment, perceive that which can barely breathe under the pressure of silence, are awarded the right to move one atom in the construction which supports the meaning. The artist transforms his existential irritation and uncompromising social attitude into a work of art. Because of this, others are able to make use of the energy of his freedom. (Potocka, 2013)

On the other hand, the fact that Stockhausen links the role of freedom and novelty in the creative process with what might be called a kind of spirituality (Geistig-Geistliche) undoubtedly provides evidence of individually conditioned 'freedom in music', freedom which as a 'relational phenomenon [...] establishes the extent of (in)dependence [...] at the crossing place between that which is individual and that which is social', and a composer as 'an individual is always entangled in a net of emotional bonds' (Korolczuk, 2013). It is sufficient to remind ourselves that Stockhausen experienced many traumatic events which ravelled emotionally the 'freedom in music' which he postulated. The trauma of war experiences, the depression he went through, thoughts of the lost love and death, finally the reading of such works as Herman Hesse's The Glass Bead Game, the

Stockhausen's thinking: to go to the limits of reason (geistig) in order to transcend it towards spirituality (geistlich)' (Peters\& Schreiber, 1999, p. 123).

${ }^{2}$ 'Wie bei allem, was ich beginne, gibt es für mich drei wesentliche Orientierungen [...]. Eine ist die Freiheit. Seit ich mich entschied [...] das Leben eines Komponisten zu leben, schwebt mir immer als höchstes Ideal die Freiheit vor [...] Das Stück, das heute abend [...] uraufgeführt wird [...], ist in völliger Freiheit entstanden, unabhängig von Zwängen und Regelnund von - wie soll ich das sagen - von Ideologie. [...] Das Zweite ist das Neue. [...] etwas zu komponieren, das alles ausschloß, was ich kannte [...] Es geht um das Neue, die Freiheit zu benutzen, nichts zu verwenden, was andere verwendet haben - auch keine gesellschaftliche Abhängigkeit zu akzeptieren. [...] Und das Neue soll Geistig-Geistliches sein' (Stockhausen, 1998a, pp. 19-20). 
writings of the Indian thinker, poet and spiritual leader Sri Aurobindo or The Book of Urantia led Stockhausen to discover in himself the role of artist-spiritual guide.

It is not religion. It is a certain attitude to life. I would prefer not to use the word 'philosophy', that is also not quite it; it would be closer to the truth to say 'a lesson of being' [...] an attitude, knowledge about life [...]. While what I do contains something of religion, it also contains many of my personal life experiences, such as my encounter with death. ${ }^{3}$ (Stockhausen, 1989, p. 296)

'Freedom in music' conditioned individually bestows on a given composition unique features not only as a result of its creator's life experiences, his interests outside music or strong influence of his readings, but is above all the effect of his formulated poetics and the realisation of creative ideas. Taking into account the fact that Stockhausen's poetics, particularly in his mature years, had a spiritual and cosmic dimension, the composer's 'sense of personal freedom and independence' should be associated with his belief that

[...] the pure, abstract arts acquire a new purpose in this development - to connect man with the mysterious vibration structures of the entire cosmos. ${ }^{4}$ (Peters \& Schreiber, 1999, p. 110)

In Stockhausen's work this idiomatic thinking about the meaning of art was accompanied by a sense of freedom in the selection of musical material, compositional means and techniques, ways of constructing works and giving them the features of specific genres. It seems that it is in this sense of independence in respect of choosing these aspects of his works that freedom and novelty reached their crossing place in Stockhausen's music.

[...] the development of music since 1950 is really radically different from everything that existed before.. [...] The material must - as far as possible - create its own sound world with each work, that has always been my requirement: Not by choosing from what already exists, like in pop music, where samples are always used, but by making something unique for each work. The timbres are also no longer decoration, are not just the instrumentation of given harmonic, melodic or rhythmic factors, but rather have their own structural value. In the music that has been composed since 1950, we are like physicists. We discover a completely new world in acoustics and in the art of forming acoustic vibrations: We not only invent, we are discoverers [...]. (Stockhausen, 2001)

As well as the self-reflection quoted here, Stockhausen's wider thinking on this subject provides evidence of the evolutionary and processual character of his works. Their essence was the realisation of the author's postulate of the need for freedom, novelty and spirituality in music (Freiheit-Das Neue-Geistig-Geistliche), bestowing on Stockhausen the status of an avant-garde composer, attuned to that which is contemporary and modern, and giving his music freedom, both as itself and within it.

\footnotetext{
${ }^{3}$ Quote from Pasiecznik, 2011, p. 80.

${ }^{4}$ '[...] die reinen, abstrakten Künste eine neue Bedeutung haben, den Menschen mit den Geheimnissen der Schwingungsstrukturen des gesamten Kosmos zu verbinden'. (Stockhausen, 1998b, p. 222, quote from: Peters\& Schreiber, 1999, p. 110)
} 


\section{Manifestations of 'freedom in music' in Stockhausen's music}

Stockhausen's 'freedom in music' is a consequence of regarding a given composition as exemplification of his own philosophical-theoretical views, frequently published in the analytical commentaries attached to the scores. In the evolution of these views - from the extreme rationalistic vision of the creative process to acceptance of irrational aspects in composing music - one can identify features indicating a conception of music in the Pythagorean-Boethian tradition, not as art but a kind of philosophy and religion. Music understood in this way was to be a kind of search for the presence of God in the symbolic organisation of the cosmos and His influence - through the cosmos - on life on Earth. It was also seen as the effect of the realisation of free choices, determined by the striving to harmonise contradictions: in art - as a form of artistic statement - as a result of combining tradition versus progress; in life - as a source of inspiration flowing from the artist's personal experiences - as a result of having regard to the postulates of strict Christian ethics versus social revolution; and finally in music, Stockhausen's natural medium for expressing creative process and liberation from outdated values - as a result of creating totally serialised compositions versus intuitive music.

It would not be possible in this relatively brief discussion to take into account all the manifestations of 'freedom in [Stockhausen's] music', but it is worthwhile devoting some space to at least some of them.

Beginning with the serial technique, Stockhausen initially introduced 'freedom [into] music' in relation to the construction of the work; as a result it was the musical structure that became the ideal for the composer; in it, no element would be superior or subordinate. This new order in the organisation of a work led to the group form, which had no genre identity but was shaped according to the postulate that the organisational principle was not to be changeability or differences, but the creation of analogies. This procedure was aimed at liberating music from the limitations imposed on it by the serial technique. What made this idea new was the presentation of such formal and technical solutions which would harmonise in a more concrete manner the contradictions in music; i.e., would reconcile the strictness of proportion and number with the subjective, uncontrolled factor. The evolution of Stockhausen's creative ideas was then aimed at establishing the principles which would 'reconcile' the measurability of number with the workings of chance, integration with dissociation, order with chaos, organisation with lack of organisation. Eliminating strict boundaries, the contrasts present in the principles of the organisation of a composition and the choice of compositional techniques bore fruit in moving the centre of gravity from the dualism of their extremes to mediation and gradation of organisation. The principle of mediation, an important aspect of Stockhausen's poetics, in general consisted in the fact that higher degree of organisation implied lesser density of events, their isolation and absence of the element of chance, while a lesser degree of organisation would strengthen the element of chance. A 
practical manifestation of the use of the principle of mediation as the principle liberating music from the limitations introduced in the serial technique was the idea of a kind of equal-rights participation; following this principle, the musical structure was decentralised by levelling the status of all the musical elements; not forming a hierarchy, they could be combined in any way. In this context, Zeitmasse from 1956 for five woodwind instruments is an example of a work in which the construction is based on mediation, and exemplified the constant change of a point/sound into a group of sounds and then - into an unidentified sound mass. This change is here rationalised as a result of using proportions of structures arranged in serial sequences (Toop, 2005, pp. 29-32). In turn, the principle of equal-rights participation influences the multidimensional autonomy of the composition, as a result of which one reading of it overlaps with another, and that in turn is a part of yet another reading; the suggested possibilities participate on equal terms in the process of understanding the main idea of time presented in Zeitmasse, hence the need to interpret the composition on many levels simultaneously (Stockhausen, 1964, pp. 46-49). Conceptualising musical time as multidimensional time meant that the composition itself would become multidimensional.

Stockhausen's 'freedom in music' manifests itself also in the composer's individualistic approach to the problem of forming a stable architectonic construction of a work and shaping its narration. He was one of the first of twentieth-century creative artists to propose the form of an open work, using this concept in relation to two types of work; the performer would decide the sequence of particular fragments of the work, or decide on the beginning and ending of a non-developmental flow of sound events, performed, in a sense, 'round-and-round' and for as long as wanted. An example of the second type of work is his Zyklus für einen Schlagzeuger from 1959, where the untypical score (16 spiral-bound pages) conveys the idea of circularity, which means that the composition can be started from any segment (which is followed by all the others) and finished on any segment (Stockhausen, 1964, pp. 73-100). The freedom achieved in Zyklus in this manner also has its consequences in the intentional treatment of the performer as the composer of the uniquely shaped - in every act of performance - form of the composition. Zyklus is also characterised by the absence of the effect of narration. Such a non-developmental flow of sound events was described by Stockhausen as the 'moment' form (Maconie, 2005, pp. 219, 242, 259). This is music understood as a continuum of sounds and silence which does not strive towards a culmination, where the aimless sequence of musical events demonstrates 'freedom in music' as a manifestation of a radical break with the tradition of European music subordinated to the principles of rhetoric and l'art dramatique. You may listen or not to such works as Momente for solo soprano, four choral groups and thirteen instrumentalists from the years 1961-64. Until the moment when the listener tunes into or tunes out of the process of conscious perception, Stockhausen would not provide any guidance, only claiming that that music had no beginning and no end (in the traditional sense), that there is no more important and less important music, and no planned culmination point. The music flows in a sense independently of the compositional intention of its author, and since it 
is of relatively long duration (ca. 80'-90') it is impossible to concentrate and the listener cannot take an active part in listening throughout. For this reason Stockhausen in a way 'relieves' the perceiver from the duty of continuous listening, at the same time recommending periodic changes from active to passive listening (Maconie, 2005, pp. 239-45). In turn, the realisation of Stockhausen's recommendation contributes to the intentional treatment of the listener as a creator of the work, since the moments of active listening determine the mental shape of the form of the work.

Undoubtedly Stockhausen incorporated ‘freedom' most radically in intuitive music. Total aleatorism, the foundation of the concept of intuitive music, 'endows' with freedom both the musical material and the construction of the work. The creative function of the composer is reduced to stimulating the free improvisation by the performers, the sense of which consisted in intuitive harmonising of the musicians in the act of performing a work with free construction linked to total openness of the form. Stockhousen's creative idea, which conditions uniquely the 'freedom' in this music, is linked to the composer's 'message'. The author does not actually create 'his' music, but acts as a translator and merely transmits 'vibrations from the cosmos', vibrations in relation to which the composer acts as a receiver. In relation to intuitive music, Stockhausen claimed that when he was composing he in a sense ceased to exist as a separate entity, and for this reason the performers should tune into sensing these 'cosmic vibrations' and, engaging their subconscious and employing contemplation and the highest degree of concentration, should melt into this suprapersonal being, so that when playing individual notes they did not focus on their articulation, but were listening out (Hamel, 1995, p. 176). An example of such broadly planned 'freedom in music' is Aus den Sieben Tagen from 1968, where the external factor generating the imagined freedom is a philosophical-metaphysical impulse; on the one hand, this impulse reaches to Stockhausen's interest in the cultures of East and West and, on the other, to linking the act of creation to the workings of mystical premonition and intellectual rationalism. In this context, Stockhausen's creative idea is born out of the composer's personal experiences, motivating him only to create fifteen poetised texts aimed at inspiring an indefinite group of performers, who are to articulate under their influence freely chosen acoustic effects. Thus the recipient perceives a work the shape and sound of which is created in each act of performance by the performers, inspired only by the composer's texts (Maconie, 1976, pp. 250-56).

Finally, it is worth quoting yet another of Stockhausen's statements testifying to the involvement of freedom of choice in the shaping of 'freedom in [the] music' of this composer.

The material itself must be a part of the act of creation. This means that when I start work on a new composition, the choice of the source of the sound, the instrument, and the sound material must all be organised or structured at once - by the method by which the work as a whole will be structured. This guarantees that the material and the form are one. You no longer create forms out of a given material, you create that material, create your own sounds. (Cott, 1974, p. 36) 
The critical impulse linked to the need for expanding the musical material by synthetic sounds, the freedom of choosing the montage technique dictated by inspiration coming from the possibilities offered by contemporary technology, as well as the freedom of constructing a work and its genre as a consequence of choosing the material and the technique, all contributed to the creation of electronic music, such as is represented by, for example, Studie II from 1954 or Gesang der Jünglige from 1956. The material and the form become one, and the intentional treatment of these works leads to eliminating the function of the performer. While 'freedom in music', electronic or live electronic music, manifests itself in closed works, they are created under the influence of the choices of the composer liberated from material and organisational limitations, in compositions that are free and new in relation to tradition.

\section{The self-reflection of Iannis Xenakis}

In the case of Xenakis, the problem of ,freedom in music' appears as a consequence of the necessity of 'redefining music' postulated by the composer, since music was regarded by the composer as a source of sensory, not intellectual, perception. In this context Xenakis '[...] was seeking such specific solutions in the creative process which would ensure the achievement of sensory dimension of a composition, responsible for the shaping of direct expression' (Humięcka-Jakubowska, 2013, p. 436).

\footnotetext{
Expression is what [...] differentiates life and non-life. [...] But [...] you want to know if, in my scores, I search to exhibit, according to the traditional model, feelings like a dream, despair or joy. That is totally different. I consider that is useless. In the 19th century, it could be like this because codified musical language was based on social conventions, which were also recognised. Today, social conventions are destroyed, and new ones have not been constructed. This is why musical vocabularies have lost their meaning, their sense. From now on we have to understand, once again, music as an abstraction and, from there, to redefine it. ${ }^{5}$ (Pauli, 1975, p. 304)
}

Xenakis's statement quoted above points to awareness of cultural conditioning in the creative process, which the composer associates with social conventions; these, having been 'destroyed' and 'not been constructed' anew, imply the necessity of redefining music. At the same time Xenakis linked the postulated necessity of 'redefining music' with a concern over its originality (Xenakis, 1984, pp. 62-6), claiming that it was precisely originality that '[...] guarantees the survival, the preservation of humanity [...]' (Humięcka-Jakubowska, 2013, p. 437).

\footnotetext{
A composer should be original, should create his own music, unaffected by influences from the past. You might even say that, in a sense, he should act as the whole Universe acts: a creative Nothingness [...]. (Xenakis, 1988a, p. 83)
}

In Xenakis's thinking about the originality of music we also find the issue of its newness. The composer refers newness to the need to formulate principles and laws which should be defined totally 'outside memory'. This means

\footnotetext{
${ }^{5}$ Quoted after Solomos, 2004, p. 132.
} 
postulating the need to break with the past, understood in such a radical manner as to claim the 'construction of [music] out of nothing'; in Xenakis's interpretation this would ensure absence of causality in a composer's activity.

In musical composition, construction must stem from originality which can be defined in extreme (perhaps inhuman) cases as the creation of new rules or laws, as far as that is possible; as far as possible meaning original, not yet known or even forseeable. Construct laws therefore from nothing, since without any causality.

But a construction from nothing, therefore totally engendered, totally original, would necessarily call upon an infinite mass of rules duly entangled. [...] Such a mass would have to cover the laws of a universe different from our own. [...] We have seen how construction stems from an originality which is defined by the creation of rules and laws outside of an individual's or even the human species' memory. (Xenakis, 1992, p. 258)

Analysing his position as a composer functioning in a precisely specific society, and thus '[...] at the crossing between that which is individual and social, cultural and political [...]' (Korolczuk, 2013), Xenakis expressed views indicating a belief in, in a sense, freedom immanently integral to the creative process, since it seems that this is how one should interpret his statement that: 'society should not be involved'.

[...] what you are doing is only your concern - society shouldn't be involved. When you're trying to do something you should feel absolutely alone, like a spark in the blackness of the universe. That's all. You're all by yourself. This connects with what I said on a more philosophical level about originality. On the level of the individual, that's how he should feel when he is creating something. (Varga, 1996, p. 211)

It is also worth stressing that, although it is difficult to find Xenakis's formulations which would refer expressis verbis to the problem of 'freedom in music', the message of his reflection indicates that the need to free himself from any creative models matured gradually in the composer's awareness.

I remember, in the early days, when I was trying to compose, I was very much in love with Bartók. The pieces I wrote sometimes bore traces of his influence. Slowly it dawned on me that I had to be much freer, much more individual.

I had to be different, otherwise it was no use. [...] Equally, I've expressed my admiration for Varèse and people have jumped to the conclusion that I must be a pupil of his, or have been influenced by him. [...] Because you admire something, it doesn't necessarily mean you resemble it. Imitation is an existential mistake. So, to escape from that trivial cycle of relationships in music, the musician, the artist, must be absolutely independent, which means absolutely alone. You must be convinced that you're doing what you must be doing, with the means at your disposal, at that particular time. If you had other means you'd be doing something different. (Varga, 1996, p. 212)

This quotation indicates that the need to be 'more free' was associated for Xenakis with the necessity of achieving creative individuality, although the composer to some extent made it dependent on the availability of appropriate compositional means, as shown by the last two sentences of the above statement.

Xenakis undoubtedly represents the attitude of a creative artist for whom the aesthetic and critical impulses, manifested in the postulate of originality and creative work in total isolation from influences of the past, imply 'freedom in [his] music'. It is also without a doubt determined on an individual basis by the composer's life experiences, as well as his interests outside music influenced 
by these experiences. As a composer and architect, placing reliance on the laws taken from the sciences, and particularly from mathematics, Xenakis searched for an explanation of the essence of art in general, and music in particular. This quest shaped many of the views which make up his highly individualised poetics.

Art has something in the nature of an inferential mechanism which constitutes the platforms on which all theories of the mathematical, physical and human sciences move about. (Xenakis, $1988 \mathrm{~b}$, p. 4) [...] it is apparent that the artist, and consequently art, must be simultaneously rational (inferential), technical (experimental) and talented (revelatory); three indispensable and coordinated modes [...] which govern art leads to the conclusion that art is richer and vaster and must necessarily initiate condensations and coagulations of intelligence; therefore, serve as a universal guide to the other sciences. (Xenakis, 1988b, p. 5-6)

This characteristic poetics also includes the belief that it is philosophy that provides the impulse to activity and creative criticism for humanity in general, and for the artist in particular.

[...] the philosophical impulse which pushes us toward truth, revelation, research, general quest, and harsh systematic criticism, not only in specialized fields but in all possible domains. (Xenakis, 1988b, p. 8)

At the end of this part of our deliberations it should be stressed that Xenakis's understanding of the role of the composer in the act of creating music was different from Stockhausen. As has already been mentioned, Stockhausen regarded himself as an artist-spiritual guide, while for Xenakis composing was a 'struggle for [one's own] existence'.

Composing, action are nothing but a struggle for existence. To be. If, however, I imitate the past, I do nothing, and consequently I am not. In other words, I am sure that I exist only if I do something different. The difference is the proof of existence, of knowledge, of participation in the affairs of the world. I'm convinced of that. (Cott, 1974, p. 50)

Xenakis's emphasis on the role of creative criticism, need for originality in composing and not surrendering to the influence of the past, 'doing something different', as well as the creative ideas relating to the acceptance of formalisation and axiomatisation ${ }^{6}$ in the creative process are reflected in the freedom of choice of compositional means and techniques, as well as the manner of constructing the work and endowing it with originality of genre.

\section{Manifestations of 'freedom in music' in the work of Xenakis}

In his conversations with Varga, Xenakis assessed his own creative stance, saying 'That's my contribution to the development of music: I use ideas in composing that are completely alien to music' (1996, p. 79). The awareness of the

\footnotetext{
6 '[...] formalization and axiomatization constitute a procedural guide, better suited to modern thought. They permit, at the outset, the placing of sonic art on a more universal plane. Once more it can be considered on the same level as the stars, the numbers, and the riches of human brain, as it was in the great periods of the ancient civilization' (Xenakis, 1992, p. 178).
} 
originality and novelty of the ideas realised in his own musical output which the composer expressed there corresponds to the highest degree to the expectations of the critics directed at twentieth-century creative artists. To recall the words of Potocka (2013) quoted earlier: 'The artist looks deeper than the ordinary person. The places on which the artist focuses attention are subjected to "analytical torment" and pushed off-balance.' Both Xenakis's self-reflective writings and his music indicate what focused the composer's attention and what he subjected to 'analytical torment', achieving 'freedom in music' in this way. His interest in concepts developed in science and philosophy, his search for theoretical foundations behind terms such as indeterminism, determinism, symmetry or references to mathematics, probability theory, group theory, unquestionably ensured for his works the feature of originality, and for himself the status of one of the most important composers of the twentieth century.

Among the works of this architect-composer, perhaps the one most closely associated with his kind of creativity is Metastaseis for orchestra from the years 1953-54. The 'freedom' contained in this music was undoubtedly inspired by an aesthetic-critical impulse, and the creative idea referred to the composer's observations outside music; this results in Xenakis being perceived as a 'geometrist and morphologist', since '[...] in his work he often started from geometric figures or, more generally - from shapes' (Iliescu, 1998, p. 89). The freedom of choice in the construction of the work in relation to Metastaseis is bound up with Xenakis's sensitivitiy to all-pervasive shapes.

\footnotetext{
It's true, however, that the question of shapes has wide-ranging connotations. Think of the undulating snake shape, for instance. It occurs in many different places: streams flow in the form of sine waves not just in mountainous areas but also across flatlands [...] The cloud, then, is a form that occurs in many places. How to produce one or how to make it change is an intriguing question - it wasn't one that music was concerned with because it didn't have the necessary tools until I arrived and realized that ideas and techniques used in science - that is, probabilities and the statistical approach - could be employed. (Varga, 1996, pp. 206-7)
}

In Metastaseis Xenakis freed the construction of the work from stasis (the title word taken from Greek means 'beyond motion'), from the static character of serial composition. Fascination with shapes was combined here with fascination with the power of mathematical transformation of the straight line, which in constructivist compositional technique found its reflection in glissando sound structures, multiplied to 46 independent instrumental parts (Xenakis, 2008, p. 46). We will not find in Metastaseis the traditional melody or correspondence between individual motifs. Absent is the traditionally constructed musical narration based on the psychological effect of building up and easing tension. The energy contained in this work results from operating with sound masses moving in sound spaces, in a manner analogous to that described in the kinetic theory of gas particles (Choong, 1996, p. 36).

A particular type of musical narration generated by modelling shapes in sound space was achieved in Mycenae Alpha from 1978, where for the first time Xenakis used UPIC (Unité Polyagogique Informatique CEMAMu) - a system enabling the creation of sounds using graphic interface (Varga, 1996, pp. 45, 110, 194-198). Another example of original construction of a composition testifying 
to the 'freedom in music' of Xenakis is the piano composition Evryali from 1973. 'By analogy to possible visualisations of the main acoustic phenomena, Xenakis made the assumption that any hypothetical curved line may multiply in such a way that it becomes a shape resembling a bush or a tree (hence the name of Xenakis's idea - arborescences), and the shape of a tree or a bush can be located on the pitch-temporal plane' (Humięcka-Jakubowska, 2013, pp. 473-4).

On the other hand the freedom in choosing the music material led Xenakis to very diverse solutions ensuring the 'freedom in music' for this composer. Their effects can be seen in, for example, musique concrète, as in the case of Concret $P H$ (1958), where the narration is provided by the crackling and hissing of burning charcoal as the only source of sound, recorded on tape and cut up into one-second fragments. Numerous transpositions and overdubbing of this recording, with minor manipulations using such techniques as splicing, change of speed of tape or mixing, shape the constantly evolving texture of this work (Varga, 1996, pp. 42, 58). In the case of the first electronic composition, Diamorphoses (1957-58), the shape of the musical surface corresponds to a combination of the violent noises of jet engines, trains and earthquake, as well as the high sounds similar to the ringing of bells. The contrasting character of these sound layers interacts with the changing density and sequence of events, creating in this way a complex but balanced form (Solomos, 2011). The works referred to here exemplify the original manner of projecting freely chosen material, which was undoubtedly guided by the sense of independence of their creator. In a conversation with Varga Xenakis claimed:

I have no basic material. In every case I start out of nothing. I consider this to be right because
I try to break away from the past. Sometimes there's some theoretical starting point. I'm not
thinking of mathematics or physics; I'm always interested in the form, in the organization of
sounds. [...] I don't force myself into a predetermined structure, I want to navigate freely. (Varga,
1996, p. 61)

Xenakis's mathematical inclination, and his interest in the problem of perception of composed music influenced the choice of compositional strategy based directly on probabilistic. Stochastic music became the distinguishing mark of Xenakis's work, at the root of which was the belief that the listener to serial music can only experience its statistical aspects. The critical impulse led the composer to conclude that the effect of listening to music organised serially is only a certain surface of this music or some mass of sound events. Searching for a solution to this perceptual situation, Xenakis assigned to stochastic laws the function of defining the 'clouds of sound points', since he was of the opinion that in perception the total sound shape formed by a group of sound events is more important than their individual pitches (Humięcka-Jakubowska, 2013, pp. 446-9). The best known composition based on the probabilistic distribution of sound events is Achorripsis for orchestra (1956-57). However, the sense of creative freedom liberated from the past also initiated the use of other strategies taken from mathematics. In Akrata for 16 wind instruments (1964-65) Xenakis turned to logic and to set theory. He also adopted set theory as the basis for the construction of Herma for piano (1960-61), and adapted the games theory, 
concerned with modelling conflict situations, in his orchestral work Stratégie (1962), where the final shape of the work depends on the interaction: chance decision (Xenakis, 1992, pp. 122-3).

Undoubtedly the quoted examples of Xenakis's works and self-reflection indicate that the 'freedom in music' of this composer appeared as the result of combining science with creativity, which happened in two ways. On the one hand, Xenakis employed theory 'by analogy with scientific concepts', in a sense poetically and metaphorically; on the other, 'musical and/or general intuitions (non-scientific ones) found a way of being realised by using tools borrowed from science' (Solomos, 2004, p. 130).

\section{Conclusion}

The examples of Stockhausen's and Xenakis's creative impulses presented here, conditioned individually, idiomatically by the composers' ideas, experiences and interests, and their choices of creative means and strategies, determined their sense of personal freedom and independence. In turn, this freedom, manifested in their self-reflection and works, implied the sensed freedom in their music. To a large extent this was a result of creative protest against the existing reality, protest against tradition, against the conventions of the past and contemporary rules. The creative output of Stockhausen and Xenakis was not limited just to music. The composers' numerous writings enabled them to formulate views on various subjects and, in relation to music, to formulate original and new proposals liberating them from outdated values. It seems that, from the perspective of our current knowledge about the activities of twentieth-century composers, we can conclude that the musical output of Stockhausen and Xenakis, manifesting 'freedom of music' and 'freedom in music', initiated a true cultural evolution.

\section{References}

Choong, K.-W. (1996). Iannis Xenakis and Elliott Carter: A Detailed Examination and Comparative Study of Their Early Output and Creativity. Brisbane: Griffith University.

Cott, J. (1974). Stockhausen. Conversations with the composer. London: Picador.

Hamel, P. M. (1995). Przez muzykę do samego siebie. [Through music to oneself] (P. Maculewicz, Trans.). Wrocław: Wydawnictwo Sartorius.

Humięcka-Jakubowska, J. (2013). Intuicja czy scjentyzm: Stockhausen - Ligeti - Nono - Berio - Xenakis - Grisey [Intuition or scientism: Stockhausen - Ligeti - Nono - Berio - Xenakis Grisey]. Poznań: Wydawnictwo PTPN.

Iliescu, M. (1998). Xenakis i Thom. Problemy morfodynamiki dźwiękowej. [Xenakis and Thom. Problems of sound morphodynamics] Muzyka, 4(171), 87-108.

Korolczuk, E. (2013). Niebezpieczne związki, czyli o granicach wolności w sztuce i w życiu. [Dangerous liaisons, or on the limits of freedom in art and life] MOCAK Forum, 2. Retrieved from https://www.mocak.pl/niebezpieczne-zwiazki-czyli-o-granicach-wolnosci-w-sztuce-i-w-zyciu-elzbieta-korolczuk 
Maconie, R. (1976). The Works of Karlheinz Stockhausen. London: Oxford University Press.

Maconie, R. (2005). Other Planets. The Music of Karlheinz Stockhausen. Lanham, Maryland, Toronto, Oxford: The Scarecrow Press.

Pasiecznik, M. (2011). Rytuat superformuly. Karlheinz Stockhausen:'Licht. Die Sieben Tage der Woche' [The ritual of superformula. Karlheinz Stockhausen: 'Licht. Die Sieben Tage der Woche']. Warsaw: Wydawnictwo Krytyki Politycznej.

Pauli, H. (1975). Iannis Xenakis im Gespräch. Schweizerische Musikzeitung, 115, 300-08.

Peters, G., \& Schreiber, M. (1999). '...How Creation is Composed': Spirituality in the Music of Karlheinz Stockhausen. Perspectives of New Music, 37(1), 97-131.

Potocka, A.M. (2013). Wolność w sztuce. [Freedom in art] MOCAK Forum, 2. Retrieved from https:// www.mocak.pl/wolnosc-w-sztuce-maria-anna-potocka

Solomos, M. (2004). Xenakis' Thought through his Writings. Journal of New Music Research, 33(2), $125^{-136 .}$

Solomos, M. (2011). Xenakis first composition in musique concrète: Diamorphoses. Retrieved from https://www.gold.ac.uk/media/documents-by-section/departments/music/Keynote-III-Makis-Solomos.pdf

Stockhausen, K. (1964). 'Zeitmaße'. In D. Schnebel (Ed.). Texte: zu eigenen Werken, zur Kunst Anderer, Aktuelles, vol. 2:Aufsätze 1952-1963 zur musikalischen Praxis, (pp. 46-49). Köln: M. DuMont Schauberg-Verlag.

Stockhausen, K. (1964). 'Zyklus' für einen Schlagzeuger. In D. Schnebel (Ed.). Texte: zu eigenen Werken, zur Kunst Anderer, Aktuelles, vol. 2: Aufsätze 1952-1963 zur musikalischen Praxis, (pp. 73-100). Köln: M. DuMont Schauberg-Verlag.

Stockhausen, K. (1989). Texte zur Musik 1977-1984, vol. 6: Interpretationen. Köln: DuMont.

Stockhausen, K. (1998a). Freiheit - das Neue - das Geistig-Geistliche. Neue Zeitschrift für Musik, $4,18-25$.

Stockhausen, K. (1998b). Texte zur Musik 1984-1991, vol. 1O: Astronische Musik, Echos von Echos. Kürten: Stockhausen-Verlag.

Stockhausen, K. (2001). We in music are like physicists - conversation with Julia Spinola on 11th September 2001 in the Musikhaus for the FAZ, published on 17th September 2001.Retrieved from https://pl.scribd.com/document/235211939/Stockhausen-Physicists

Toop, R. (2005). Six Lectures from the Stockhausen Courses Kürten 2002. Kürten: Stockhausen-Verlag.

Varga, B. A. (1996). Conversations with Iannis Xenakis. London: Faber and Faber.

Xenakis, I. (1984). Musique et originalité. Phréatiques, 28, 62-66.

Xenakis, I. (1988a). Determinizm-indeterminizm. (M. Harley, Trans.). Warsaw: Polskie Towarzystwo Muzyki Współczesnej.

Xenakis, I. (1988b). Arts/Sciences: Alloys. Stuyvesant, NY: Pendragon Press.

Xenakis, I. (1992). Formalized Music. Thought and Mathematics in Composition. (Ch. Butchers, Trans.). New York: Pendragon Press.

Xenakis, I. (2008). Music and Architecture. (S. Kanach, Trans.). New York: Pendragon Press. 